\title{
SEDIAAN KRIM EKSTRAK AIR BUAH AREN (Arenga pinnata) SEBAGAI ANTIOKSIDAN
}

\author{
Riny Erfiah Rinda, A. Mumtihanah Mursyid, A. Hasrawati \\ Fakultas Farmasi, Universitas Muslim Indonesia, Makassar \\ Email: rinyerfiah@gmail.com
}

\begin{abstract}
Palm fruit (Arenga pinnata) contains galactomannan which has the potential as an antioxidant activity with an $I C_{50}$ value of $20,45 \mathrm{ppm}$. This study aims to produce cream dosage forms with antioxidant activity using the scaverry DPPH radical scavenger method from arenga pinnata water extract. Palm fruit water extract is formulated in cream form with variations in the concentration of stearic acid and triethanolamine emulgators in F1 (6:4), F2 (7:3), and F3 (8:2). Evaluation of physical stability includes organoleptic testing, homogeneity, $\mathrm{pH}$, emulsion type, viscosity and type of flow carried out before and after forced conditions. In the statistical analysis of viscosity, the results of each formula showed no significant changes both before and after the conditions were forced. The results of the study obtained formula 2 and formula 3 has optimal stability. The stable formula was then tested for antioxidants using the DPPH (1,1-Diphenyl-2-Picrylhydrazyl) radical scavenger method. Formula 2 and formula 3 each yield a DPPH radical inhibition percentage of $65 \%$ and $48.04 \%$.
\end{abstract}

Key words: Arenga Pinnata, creams, antioxidants.

\section{PENDAHULUAN}

Radiasi ultraviolet (UV) di pancarkan oleh matahari dapat menyebabkan pembentukan radikal bebas yang merupakan molekul dengan satu atau lebih elektron yang tidak berpasangan kemudian bereaksi dengan berbagai substrat organik seperti lipid, protein dan DNA sehingga memiliki efek merugikan bagi manusia yaitu mempercepat proses penuaan kulit dan memicu terjadinya kanker kulit. $^{1,2}$

Antioksidan dapat melindungi sel dengan berperan dalam menetralkan radikal bebas yang berlebih. Menurut jalur produksinya, antioksidan terbagi atas antioksidan alami, antioksidan sintetis dan antioksidan alami-identik. Antioksidan alami disintesis oleh berbagai mikroorganisme, jamur, hewan, dan tanaman. ${ }^{1,3}$

Berdasarkan hasil penelitian Yanti et $\mathrm{al}^{(4)}$ buah aren (Arenga pinnata) memiliki kandungan galaktomanan yang berpotensi sebagai aktivitas antioksidan dengan $\mathrm{IC}_{50} 20$, 45 ppm. Buah aren (Arenga pinnata) yang diaplikasikan ke wajah secara langsung ataupun dalam bentuk ekstrak akan terasa sulit dan tidak nyaman pemakaiannya sehingga dapat diformulasi menjadi sediaan kosmetik dalam bentuk krim. ${ }^{5}$

Krim merupakan tipe emulsi yang memberikan efek melembabkan, mudah tersebar merata, mudah berpenetrasi pada kulit, memberikan efek dingin karena lambatnya penguapan air pada kulit, serta pelepasan obat yang baik. Formulasi topikal berupa krim yang efektif dapat mengantarkan antioksidan ke dalam kulit wajah untuk melindungi sel akibat serangan radikal bebas. $^{6,7}$

Pada penelitian ini ekstrak air buah aren (Arenga pinnata) akan diformulasikan menjadi sediaan krim yang memiliki aktivitas 
antioksidan dan kemudian diuji aktivitas antioksidannya dengan menggunakan metode DPPH.

\section{METODE PENELITIAN}

\section{Alat dan bahan}

Alat yang digunakan adalah alat-alat kaca (Pyrex) blender (Miyako), cawan porselin, climatic chamber (Memmert), freeze dryer (LyovaporTM L-200), lemari pendingin (Modena), kaca bulat, mixer (Miyako), mikropipet, penangas air (Cimarec), pH meter, sentrifug (PLC-05), spektrofotometer uv-vis (Thermo), tabung sentrifug, termometer, timbangan analitik (Kern), viskometer (Brookfield), dan waterbath. Bahan yang digunakan adalah aluminium foil, asam stearat, aquadest, ekstrak air buah aren (Arenga pinnata), DPPH (1,1-Diphenyl-2Picrylhydrazyl), etanol, kertas saring, natrium metabisulfit, metanol, metil paraben, minyak zaitun, minyak melati, propilen glikol, propel paraben, setil alkohol, titanium dioksida, dan trietanolamin.

\section{Prosedur Penelitian}

\section{Ekstraksi Buah Aren}

Sebanyak 227 gram buah aren (Arenga pinnata) ditambah dengan $2750 \mathrm{~mL}$ aquades, dihaluskan dengan blender dan disimpan dalam lemari pendingin selama 24 jam. Kemudian disentrifugasi pada kecepatan 9500 rpm selama 15 menit. Supernatan (I) dipisahkan dari residu. Residu ditambahkan air suling sebanyak $1375 \mathrm{~mL}$ dan disentrifugasi pada kondisi yang sama. Supernatan (II) dipisahkan dari residu. Supernatan I dan II digabung dan ditambah etanol 96\% dengan perbandingan volume 1:2. Endapan yang terbentuk disaring dan dikeringkan dengan freeze drying.,

\section{Rancangan Formula}

Ekstrak air buah aren (Arenga pinnata) sebanyak 2,045 \% sebagai bahan akitf, trietanolamin dan asam Stearat sebagai emulgator dengan variasi konsentrasi pada formula 1 (4:3) \%, formula 2 (3:7) \%, formula 3 $(2: 8) \%$, minyak zaitun sebagai basis (10\%), propilen glikol sebagai humektan (10\%), metil paraben dan propil paraben sebagai pengawet $(0,4 \%)$, setil alkohol sebagai emolien dan peningkat viskositas $(4,5 \%)$, titanium dioksidann sebagai opacifier $(0,1 \%)$, natrium metabisulfit sebagai antioksidan sediaan $(0,1$ $\%$, minyak melati sebagai pengaroma (setetes) dan aquades sebagai pelarut (add $100 \mathrm{~mL}$ ).

\section{Pembuatan sediaan krim}

Fase minyak dibuat dengan cara melarutkan minyak zaitun, asam stearat, setil alkohol, dan propil paraben di atas penangas air hingga $70^{\circ} \mathrm{C}$. Kemudian fase air dibuat dengan cara melarutkan metil paraben, natrium metabisulfit dan trietanomanin dalam air yang telah dipanaskan hingga $70^{\circ} \mathrm{C}$. Fase minyak kedalam fase air sambil menggunakan mixer hingga terbentuk emulsi. Pengadukan dilakukan dengan intermittan shaking. Kemudian ditambahkan sedikit demi sedikit ekstrak buah aren yang telah dilarutkan dengan propilen glikol. Ditambahkan titanium dioksida dan setetes minyak melati. Dihomogenkan hingga terbentuk emulsi.

\section{Evaluasi Kestabilan Fisik}

Dilakukan evaluasi stabilitas fisik sediaan krim dengan parameter uji organoleptik, uji homogenitas, penentuan tipe emulsi, pemeriksaan $\mathrm{pH}$, uji daya sebar, uji viskoitas dan tipe aliran. ${ }^{7,9}$ 


\section{Stabilitas Kondisi Dipaksakan}

Evaluasi stabilitas dengan kondisi dipaksakan dilakukan selama 10 siklus. Satu siklus sama dengan penyimpanan pada suhu $5 \stackrel{\circ}{\circ}$ selama 12 jam dan pada suhu $35 \stackrel{\circ}{ } \mathrm{C}$ selama 12 jam. $^{10}$

\section{Uji Aktivitas Antioksidan Sediaan Krim}

\section{Buah Aren}

\section{Pembuatan dan Pengukuran Panjang Gelombang Maksimum Larutan DPPH 60 ppm sebagai kontrol}

Sebanyak $6 \mathrm{mg}$ DPPH dilarutkan dengan metanol hingga $100 \mathrm{~mL}$. Dihomogenkan dan ditempatkan dalam botol gelap. Dipipet $2 \mathrm{~mL}$ larutan DPPH (60 ppm) ke dalam vial. Lalu ditambah metanol $2 \mathrm{~mL}$ dan dihomogenkan. Kemudian diinkubasi dalam ruangan gelap selama 30 menit. Ditentukan spektrum serapannya menggunakan spektrofotometer UV-Vis pada panjang gelombang 400-800 nm dan ditentukan panjang gelombang maksimumnya. ${ }^{11}$

Penyiapan dan pengujian aktivitas antioksidan sampel krim

Ditimbang 2,5 gram krim, lalu dilarutkan dengan metanol sebanyak $5 \mathrm{~mL}$. Kemudian dilakukan sentrifugasi selama 10 menit dengan kecapatan $3000 \mathrm{rpm}$. Filtrat disaring dan dipipet sebanyak $2 \mathrm{~mL}$ kedalam vial. Kemudian ditambahkan larutan DPPH (60 ppm) sebanyak $2 \mathrm{~mL}$ dan diinkubasi selama 30 menit dalam ruangan gelap. Selanjutnya diukur menggunakan spektrofotometri UV-Vis pada panjang gelombang 516,8 $\mathrm{nm}$. Dihitung persen hambatannya dengan rumus: ${ }^{11,12}$

$\%$ Inhibisi $=\frac{a-b}{a} \times 100 \%$

Keterangan:

$a=$ Absorbansi kontrol

$\mathrm{b}=$ Absorbansi sampel

\section{HASIL DAN PEMBAHASAN}

Buah aren (Arenga pinnata) merupakan tumbuhan dari famili arecaceae yang mengandung senyawa galaktomanan berupa polimer manosa dan galaktosa. Galaktomanan buah aren memiliki sifat antioksidan dengan $\mathrm{IC}_{50}$ sebesar $20,45 \mathrm{ppm} .{ }^{4,5}$

Ekstrak air buah aren (Arenga pinnata) diformulasikan menjadi sedian krim tipe emulsi m/a. Pemilihan tipe emulsi bertujuan untuk menghasilkan sediaan yang dapat menghantarkan antioksidan kedalam kulit wajah sehingga memberi efek mencerahkan dan mencegah penuaan dini. Penggunaan tipe emulsi m/a dapat digunakan pada sepanjang hari karena terasa ringan dan tidak berminyak. ${ }^{4,13}$

Pada sediaan digunakan kombinasi emulgator yaitu asam stearat dan trietanolamin. Pada formulasi digunakan konsentrasi emulgator dengan perbandingan yang berbeda yang bertujuan untuk memperoleh formula yang stabil pada sediaan krim . Pengujian kestabilan dilakukan dengan metode kondisi dipaksakan dengan penyimpanan pada suhu $5{ }^{\circ} \mathrm{C}$ dan $35 \stackrel{\circ}{\circ} \mathrm{C}$ selama 10 siklus, masing-masing siklus berdurasi 12 jam. Tujuan dilakukannya kondisi dipaksakan adalah untuk mengevaluasi sediaan dan untuk mempersingkat waktu pengujian. $^{10}$

Pengujian organoleptik bertujuan untuk melihat kestabilan fisik dari sediaan krim dengan melihat perubahan warna, bau dan konsistensi pada sediaan selama penyimpanan. Sedangkan pengujian homogenitas bertujuan untuk melihat distribusi partikel dari sediaan. 
Tabel 1. Hasil pengamatan uji organoleptik dan homogenitas sediaan krim ekstrak air buah aren (Arenga pinnata)

\begin{tabular}{cccccc}
\hline \multirow{2}{*}{ Formula } & \multirow{2}{*}{ Kondisi } & \multicolumn{4}{c}{ Jenis Pemeriksaan } \\
\cline { 3 - 5 } & & Bau & Warna & Konsistensi & Homogenitas \\
\hline \multirow{2}{*}{ Formula 1 } & Sebelum & Melati & Putih & Kental & Homogen \\
& Sesudah & Melati & Putih & Kental & Homogen \\
\hline \multirow{2}{*}{ Formula 2 } & Sebelum & Melati & Putih & Kental & Homogen \\
& Sesudah & Melati & Putih & Kental & Homogen \\
\hline \multirow{2}{*}{ Formula 3 } & Sebelum & Melati & Putih & Kental & Homogen \\
& Sesudah & Melati & Putih & Kental & Homogen \\
\hline
\end{tabular}

Pada tabel 2 menunjukkan bahwa sebelum dan sesudah kondisi dipaksakan tidak terjadi perubahan berupa aroma, warna, dan konsistensi pada semua formula. Uji homogenitas juga menunjukkan bahwa semua formula memiliki partikel yang terdistribusi secara merata.

Penentuan tipe emulsi bertujuan untuk mengetahui tipe emulsi yang terbentuk dari sediaan krim dengan menggunakan metode konduktivitas yang didasarkan prinsip bahwa air menghantarkan aliran listrik bila fase air bertindak sebagai fase luar sedangkan minyak sebaliknya. Apabila jarumnya bergerak maka tipe emulsinya adalah m/a dan jarumnya tidak bergerak maka tipe emulsinya adalah $\mathrm{a} / \mathrm{m} .^{14}$

Tabel 2. Hasil penentuan tipe emulsi sediaan krim ekstrak air buah aren (Arenga pinnata)

\begin{tabular}{ccc}
\hline Formula & & Kondisi \\
\cline { 2 - 3 } & Sebelum & Sesudah \\
\hline Formula 1 & $\mathrm{m} / \mathrm{a}$ & $\mathrm{m} / \mathrm{a}$ \\
Formula 2 & $\mathrm{m} / \mathrm{a}$ & $\mathrm{m} / \mathrm{a}$ \\
Formula 3 & $\mathrm{m} / \mathrm{a}$ & $\mathrm{m} / \mathrm{a}$ \\
\hline
\end{tabular}

Pada penelitian menunjukkan jarum konduktor yang bergerak. Berdasarkan teori, hal tersebut menandakan adanya fase air pada fase luar emulsi maka tipe emulsi yaitu $\mathrm{m} / \mathrm{a}$. Semua formula menghasilkan tipe emulsi $\mathrm{m} / \mathrm{a}$ baik sebelum dan sesudah kondisi dipaksakan. Hasil ini sesuai dengan tujuan formulasi awal yaitu memformulasi krim tipe emulsi tersebut.
Pengujian $\mathrm{pH}$ bertujuan untuk mengetahui keamanan sediaan saat digunakan. $\mathrm{pH}$ yang tidak sesuai dengan $\mathrm{pH}$ kulit dapat menyebabkan iritasi pada waktu pemakaiannya. Standar yang diisyaratkan SNI 16-4399-1996 pH pelembab kulit berkisar 4,5$8,0 .^{15}$

Tabel 3. Hasil uji pH sediaan krim ekstrak air buah aren (Arenga pinnata)

\begin{tabular}{ccc}
\hline Formula & \multicolumn{3}{c}{$\mathbf{p H}$} \\
\cline { 2 - 3 } & Sebelum & Sesudah \\
\hline Formula 1 & $8,3 \pm 0,2$ & $8,5 \pm 0,05$ \\
Formula 2 & $7,5 \pm 0,2$ & $7,7 \pm 0,6$ \\
Formula 3 & $7,4 \pm, 1$ & $7,5 \pm 0,2$ \\
\hline
\end{tabular}


Pengujian $\mathrm{pH}$ tidak menghasilkan perubahan yang signifikan pada semua formula sebelum sesudah kondisi dipaksakan. $\mathrm{pH}$ dari Formula 1 melewati range $\mathrm{pH}$ kulit, sedangkan pada formula 2 dan formula 3 memenuhi syarat untuk kisaran $\mathrm{pH}$ kulit sehingga aman digunakan.
Pengujian daya sebar dilakukan untuk mengetahui kemampuan penyebaran sediaan krim saat diaplikasikan ke kulit. Penyebaran basis yang baik akan memberikan kemudahan pengaplikasian ke permukaan kulit. Kisaran daya sebar yaitu $5-7 \mathrm{~cm}^{9}$

Tabel 4. Hasil uji daya sebar sediaan krim ekstrak air buah aren (Arenga pinnata)

\begin{tabular}{llcccc}
\hline \multirow{2}{*}{ Kondisi } & \multirow{2}{*}{ Formula } & \multicolumn{4}{c}{ Daya Sebar Rata-Rata (cm) } \\
\cline { 3 - 6 } Sebelum & $\mathbf{0}$ & $\mathbf{5 0}$ & $\mathbf{1 0 0}$ & $\mathbf{1 5 0}$ \\
& Formula 1 & $6,5 \pm 0,2$ & $7 \pm 0,05$ & $7,5 \pm 0,05$ & $8 \pm 0,05$ \\
& Formula 2 & $4,7 \pm 0,5$ & $5,2 \pm 0,6$ & $5,6 \pm 0,6$ & $5,9 \pm 0,7$ \\
& Formula 3 & $5 \pm 0,3$ & $5,3 \pm 0,5$ & $5,4 \pm 0,5$ & $5,7 \pm 0,7$ \\
\hline \multirow{3}{*}{ Sesudah } & Formula 1 & $5,6 \pm 0,3$ & $6,1 \pm 0,6$ & $6,4 \pm 0,8$ & $6,6 \pm 1$ \\
& Formula 2 & $4,7 \pm 0,3$ & $5,7 \pm 0,5$ & $6,2 \pm 0,7$ & $6,5 \pm 0,7$ \\
& Formula 3 & $5 \pm 0,2$ & $5 \pm 0,4$ & $5,3 \pm 0,5$ & $5,6 \pm 0,5$ \\
\hline
\end{tabular}

Pada tabel 5 nilai daya sebar pada formula 2 dan formula 3 memasuki kisaran daya sebar sehingga mudah digunakan pada kulit. Hasil pengujian terjadi perubahan setelah kondisi dipaksakan. Hal ini dipengaruhi oleh viskositas karena semakin rendah viskositas maka diameter daya sebar sediaan akan semakin tinggi. ${ }^{16}$

Tabel 5. Hasil uji viskositas sediaan krim ekstrak air buah aren (Arenga pinnata)

\begin{tabular}{ccc}
\hline \multirow{2}{*}{ Formula } & \multicolumn{2}{c}{ Viskositas (poise) } \\
\cline { 2 - 3 } & Sebelum & Sesudah \\
\hline Formula 1 & $118,667 \pm 15,143$ & $93,067 \pm 28,958$ \\
Formula 2 & $149,867 \pm 67,676$ & $120 \pm 55,569$ \\
Formula 3 & $156 \pm 31,240$ & $124,267 \pm 39,161$ \\
\hline
\end{tabular}

Pengujian viskositas bertujuan untuk mengetahui seberapa besar ukuran dari suatu cairan atau sediaan untuk dapat mengalir. Pada tabel 6 menunjukkan terjadinya penurunan viskositas sesudah kondisi dipaksakan pada semua formula. Salah satu faktor terjadinya penurunan viskositas yaitu suhu. Viskositas akan menurun dengan naiknya suhu. Suhu tinggi akan memperbesar jarak antar partikel sehingga gaya antar partikel akan berkurang. Jarak yang semakin besar menyebabkan viskositas semakin menurun. ${ }^{17}$

\begin{abstract}
Data viskositas yang diperoleh dianalisis secara statistik dengan menggunakan metode rancangan acak kelompok (RAK). Hasil analisis menunjukkan bahwa viskositas dari masing-masing formula tidak menunjukan perubahan yang signifikan baik sebelum dan sesudah kondisi dipaksakan. Hal ini menunjukkan bahwa adanya kondisi penyimpanan pada suhu $5 \stackrel{\circ}{\circ} \mathrm{C}$ dan $35 \stackrel{\circ}{\circ}$ tidak mempengaruhi viskositas pada sediaan.
\end{abstract}



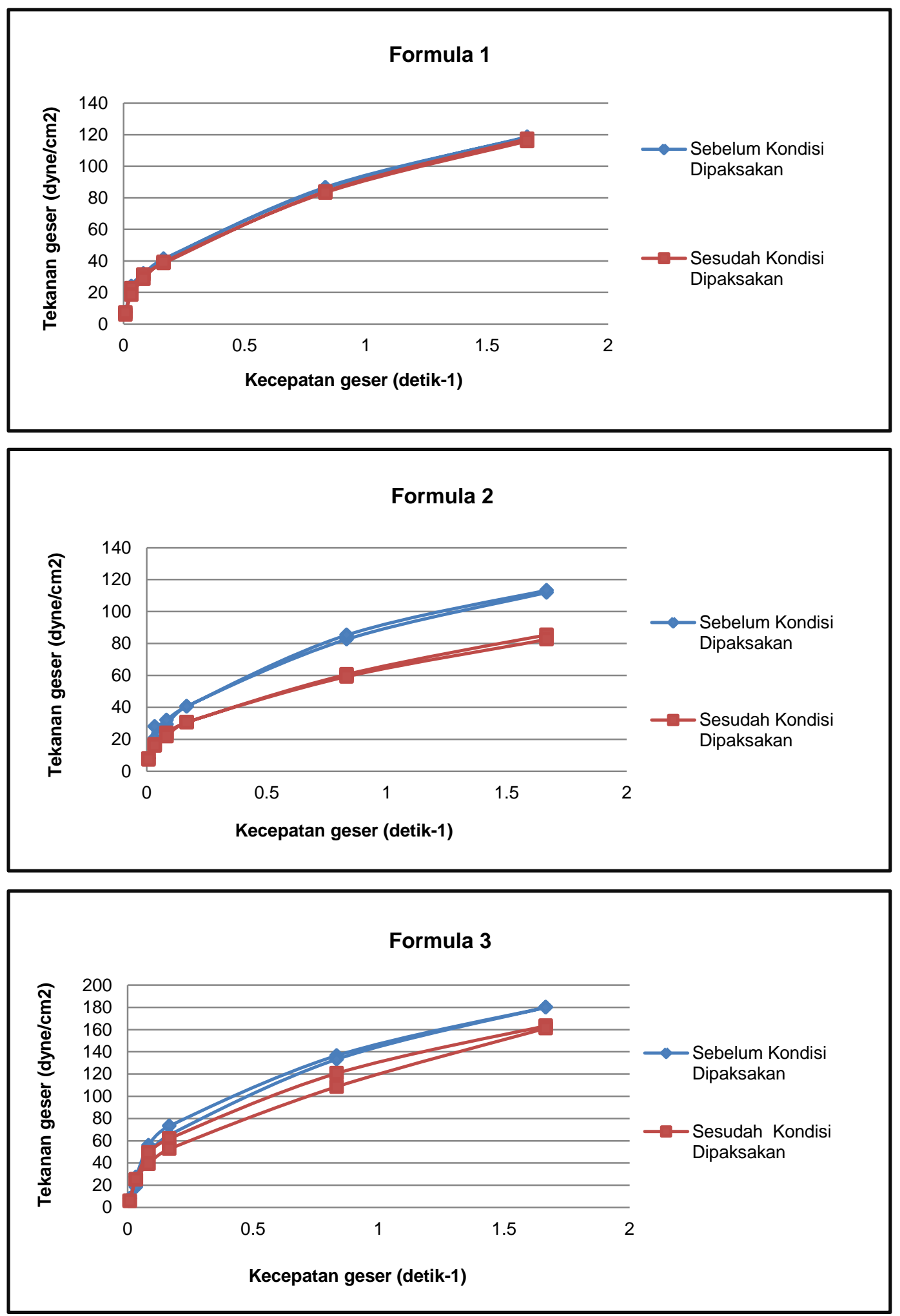

Gambar 1. Rheogram formula 1,2,dan 3 sediaan krim ekstrak air buah aren (Arenga pinnata)

Penentuan tekanan geser dan kecepatan geser menghasilkan grafik tipe aliran (rheogram) dari sediaan. Pada formula 1 menunjukkan tipe aliran plastis. Pada formula
2 menunjukkan tipe aliran thiksotropik-plastis. Dikatakan thiksotropik karena aliran menaik dan menurunnya tidak berhimpitan sehingga terbentuk hysteresis loop. Sedangkan aliran 
plastis ditunjukkan kurva yang tidak memotong titik 0,0 tetapi memotong sumbu tekanan geser pada nilai yield. Nilai yield adalah harga yang harus dipenuhi agar sediaan dapat mengalir. Adanya nilai yield disebabkan oleh kontak antara partikel-partikel yang berdekatan, yang harus dipecah terlebih dahulu agar sediaan mengalir. Pada rheogram formula 3 menunjukkan tipe aliran thiksotropik pseudoplastik. Dikatakan pseudoplastik karena menunjukkan kurva yang memotong titik 0,0 sehingga tidak ada nilai yield. ${ }^{10}$

Tabel 6. Hasil pengujian sediaan krim dengan metode peredaman radikal bebas DPPH

\begin{tabular}{ccccc}
\hline \multirow{2}{*}{ Formula } & \multicolumn{2}{c}{$\begin{array}{c}\text { Krim Ekstrak Air Buah Aren (Arenga } \\
\text { pinnata) tanpa natrium metabisulfit }\end{array}$} & \multicolumn{2}{c}{$\begin{array}{c}\text { Krim Ekstrak Air Buah Aren (Arenga } \\
\text { pinnata) }\end{array}$} \\
\cline { 2 - 5 } & Absorbansi & \% Inhibisi & Absorbansi & \% Inhibisi \\
\hline Formula 2 & 0,407 & 48,54 & 0,270 & 65 \\
Formula 3 & 0,470 & 40,58 & 0,411 & 48,04 \\
\hline
\end{tabular}

Pengujian aktivitas antioksidan dilakukan pada sediaan yang dinyatakan stabil secara farmasetika yaitu pada formula 2 dan 3. Pengujian tersebut dilakukan dengan metode peredaman radikal bebas DPPH menggunakan spektrofometer uv-vis. Hasil penetapan panjang gelombang maksimal larutan DPPH 60 ppm adalah 516,8 nm Berdasarkan tabel 7 menunjukan bahwa kedua formula memiliki aktivitas antioksidan karena dapat menghambat radikal bebas DPPH. Formula 2 menunjukkan krim antioksidan yang memiliki nilai paling optimal dari formula 3.

\section{KESIMPULAN}

Hasil penelitian diperoleh formula 2 dan formula 3 memiliki kestabilan yang optimal. Formula 2 dan formula 3 masingmasing menghasilkan persen penghambatan radikal DPPH adalah $65 \%$ dan 48,04\%.

\section{DAFTAR PUSTAKA}

1. Pham-Huy LA, He H, Pham-huy C. Free Radicals, Antioxidants in Disease and Health. Free Radicals And Antioxidants 2008; 4(2):8.

2. Altmeyer $\mathrm{P}$, Braun-Falco $\mathrm{O}$, Horstmann $\mathrm{A}$, Freitag M, Hoffmann K, Stücker M. Skin Cancer and UV Radiation, 1997.
3. Cirilo G, Lemma F. Antioxidant Polymers: Synthesis, Properties, And Applications. Scrivener Wiley, 2012.

4. Yanti, Madriena, Ali S, Cosmeceutical Effects Of Galactomannan Fraction From Arenga Pinnata Fruits In Vitro. Pharmacognosy Research, 2017; 9(1):39.

5. Tarigan JB, Barus T, Kaban J, Marpongahtun. Characteristic and Study Of Antioxidant Activity Galactomannan from 'Kolang-kaling' (Arenga pinnata). Asian International Conference On Material, Minerals and Polymer, 2012.

6. Draelos ZD. Cosmetic Dermatology: Products and Procedures. WileyBlackwell, 2010.

7. Juwita AP, Yamlean P, Edy HJ. Formulasi Krim Ekstrak Etanol Daun Lamun (Syringodium isoetifolium). Pharmacon Jurnal IImiah Farmasi, 2013; 2(02):6.

8. Tarigan JB. Karakterisasi Polisakarida Galaktomanan Kolang Kaling (Arenga pinnata) Terikat Silang Fosfat. Majalah Polimer Indonesia, 2015; 18(1):8

9. Shovyana H, Zulkarnain AK. Physical Stability And Activity Of Cream W/O Etanolik Fruit Extract Mahkota Dewa (Phaleria macrocharph (scheff.) Boerl) As a sunscreen. Traditional Medicine Journal, 2013; 18(2):1410—5918.

10. Mursyid AM, Evaluasi Stabilitas Fisik Dan Profil Difusi Sediaan Gel (Minyak Zaitun), Jurnal Fitofarmaka Indonesia, 2017; 4(1):205-211 . 
11. Ismail I, Handayany G, Armisman A, Ratnasari W. Formulasi Dan Uji Efektifitas Antioksidan Krim Ekstrak Etanol Korteks Kayu Jawa (Lannea Coromandelica Hout Merr) Dengan Metode DPPH. JF FIK UINAM, 2015;2(3):93-98.

12. Juniarka IGA, Lukitaningsih E, Noegrohati S. Analisis Aktivitas Antioksidan Dan Kandungan Antosianin Total Ekstrak Dan Liposom Kelopak Bunga Rosella (Hibiscus Sabdariffa L.). Majalah Obat Tradisional, 2011;16(3):115 - 123

13. Paye M, Barel AO, Maibach HI. Handbook Of Cosmeutic Science And Technology, CRC Press, 2016.

14. Aulton ME, Taylor MG. Aulton's Pharmaceutics: The Design and Manufacture of Medicines, Elsevier, 2013.
15. Ahmad I, Agus ASR. Uji Stabilitas Formula Krim Tabir Surya Ekstrak Umbi Bawang Dayak (Eleutherine americana L. Merr.), Journal Of Tropical Pharmacy And Chemistry, 2013; 2(3), 159-165.

16. Sayuti NA. Formulasi dan Uji Stabilitas Fisik Sediaan Gel Ekstrak Daun Ketepeng Cina (Cassia alata L.). Jurnal Kefarmasian Indonesia, 2015; 5(2):74-82.

17. Suryani, Putri AEP, Agustyiani $P$, Formulasi Dan Uji Stabilitas Sediaan Gel Ekstrak Terpurifikasi Daun Paliasa (Kleinhovia Hospita L.) Yang Berefek Antioksidan. Pharmavon Jurnal IImiah Farmasi-Unsrat, 2017; 6(3):13. 